\title{
ROOT MORPHOLOGY AND NUTRIENT UPTAKE KINETICS BY AUSTRALIAN CEDAR CLONES ${ }^{1}$
}

\author{
RAQUEL OLIVEIRA BATISTA ${ }^{2 *}$, ANTONIO EDUARDO FURTINI NETO ${ }^{3}$, SOAMI FERNANDA CAIO DECCETTI $^{2}$, \\ CASSIANO SILVA VIANA ${ }^{4}$
}

\begin{abstract}
Evaluation of root morphology and kinetic parameters assist in the characterization of genotypes in nutrient uptake efficiency. This study characterized Australian cedar clones concerning their nutrient uptake capacity at the seedling stage through root morphology and the kinetics of $\mathrm{P}, \mathrm{K}, \mathrm{Ca}$, and $\mathrm{Mg}$ uptake. The experiment was conducted using a nutrient solution in a greenhouse and growth chamber. Four Australian cedar clones (HE, XF, XD, and XE), provided by Bela Forest View (Empresa Florestal Bela Vista), were tested using a completely randomized design with five repetitions, totaling 20 experimental plots. The length, volume, surface area, average diameter, and root length per diameter class, as well as the uptake parameters $\mathrm{V}_{\max }, \mathrm{K}_{\mathrm{m}}, \mathrm{C}_{\min }$, and the estimated inflow of $\mathrm{P}, \mathrm{K}, \mathrm{Ca}$, and $\mathrm{Mg}$, were determined. The root morphological characteristics varied between Australian cedar clones; clone XD exhibited the largest root system development. The uptake efficiency of $\mathrm{P}, \mathrm{K}, \mathrm{Ca}$, and $\mathrm{Mg}$ varied between cedar Australian clones. When availability differed, clones XE and XF exhibited greater plasticity in the uptake of $\mathrm{P}$ and $\mathrm{K}$ respectively, and similar results were found for clone $\mathrm{HE}$ in the uptake of $\mathrm{Ca}$ and $\mathrm{Mg}$.
\end{abstract}

Keywords: Morphological attributes of root systems. Kinetic parameters. Inflow of P, K, Ca, and Mg. Nutrient uptake. Toona ciliata.

\section{MORFOLOGIA RADICULAR E CINÉTICA DE ABSORÇÃO DE NUTRIENTES POR CLONES DE CEDRO-AUSTRALIANO}

RESUMO - Avaliações da morfologia radicular e de parâmetros cinéticos auxiliam na caracterização de genótipos quanto à eficiência de absorção de nutrientes. O objetivo deste trabalho foi caracterizar clones de cedro-australiano quanto à capacidade de absorção de nutrientes na fase de muda, por meio da determinação de características morfológicas radiculares e dos parâmetros cinéticos de absorção de $\mathrm{P}, \mathrm{K}, \mathrm{Ca} \mathrm{e} \mathrm{Mg}$. O experimento foi conduzido em solução nutritiva em casa de vegetação e câmara de crescimento. Foram testados quatro clones de cedro-australiano (HE, XF, XD e XE), provenientes da empresa Bela Vista Florestal, sendo utilizado o delineamento inteiramente casualizado com cinco repetições, totalizando em vinte parcelas experimentais. Determinou-se o comprimento, volume, área superficial, diâmetro médio e extensão de raízes por classes de diâmetro, bem como os parâmetros de absorção Vmax, Km, Cmin e o influxo estimado para P, $\mathrm{K}$, Ca e Mg. As características morfológicas radiculares variam entre os clones de cedro-australiano, tendo destaque para o clone XD que apresentou um maior desenvolvimento do sistema radicular. A eficiência de absorção de $\mathrm{P}, \mathrm{K}, \mathrm{Ca}$ e $\mathrm{Mg}$ varia entre os clones de cedro-australiano. Em condições de variações na disponibilidade, os clones XF e XE apresentam maior plasticidade na absorção de $\mathrm{P}$ e $\mathrm{K}$, respectivamente, e o clone $\mathrm{HE}$ na absorção de $\mathrm{Ca}$ e $\mathrm{Mg}$.

Palavras-chave: Atributos morfológicos do sistema radicular. Parâmetros cinéticos. Influxos de P, K, $\mathrm{Ca}$ e Mg.Absorção de nutrientes. Toona ciliata.

\footnotetext{
*Corresponding Author

${ }^{1}$ Received for publication in 04/08/2014; accepted in 11/16/2015.

Thesis article for the Doctorate in Soil Science of the first author.

${ }^{2}$ Department of Soil Science, Universidade Federal de Lavras, Lavras, MG, Brazil; batista.raqueloliveira@gmail.com, deccetti@yahoo.com.br.

${ }^{3}$ Vale Institute of Technology - Sustainable Development, Belém, PA, Brazil; afurtini@dcs.ufla.br.

${ }^{4}$ Manancial Agronegócios, Porto Nacional, TO, Brazil; casss.viana@hotmail.com.
} 


\section{INTRODUCTION}

Cultivation in low fertile, natural soils is common for planted forests in Brazil. These soils require application of high doses of fertilizers for nutrient replacement, to ensure satisfactory crop yields. Optimizing the cost-benefit relationship is a challenge for entrepreneurs in the forestry sector. Innovations in genetics and nutrient absorption could help achieve this balance (HORN et al., 2006; PINTO et al., 2011).

For the characterization of species and genotypes as to the absorption efficiency of ions, evaluation of the morphological and physiological aspects of the plants involved in this process has been used as a tool (ANGHINONI et al., 1989). The morphological aspects include the root system, which may show variations among plant species with regard to in nutrient uptake capacities (ABICHEQUER; BOHNEN, 2008; PINTO, 2009; SAMAL et al., 2010; SANES et al., 2013). Moreover, the nutrient uptake efficiency may be influenced by physiological variations, as well as kinetic parameters, such as the maximum uptake velocity $\left(\mathrm{V}_{\max }\right)$, the Michaelis-Menten constant $\left(\mathrm{K}_{\mathrm{m}}\right)$, and the minimum nutrient concentration in the soil $\left(\mathrm{C}_{\min }\right)$. The interaction of these parameters is estimated through the inflow of nutrients (ALVES et al., 2012; FURTINI NETO, 1994; LIMA et al., 2005; NIELSEN; BARBER, 1978; PINTO, 2009).

Ideally, plants should have a well-developed root system, capable of exploring a greater soil volume, and improved kinetic parameters to increase nutrient uptake. The fact that most Brazilian soils used for forest plantations are limited in nutrients, emphasizes the importance of selecting genotypes that have lower $\mathrm{K}_{\mathrm{m}}$ (NOVAIS; MELO, 2007) and $\mathrm{C}_{\min }$ values (HORN et al., 2006); in principle, these genotypes could be used to compensate for the low element levels in the soil.

The search for genetically acclimatized tree lines is of interest to the forestry sector, because it allows distinct genotypes to be optimized for the site (FURTINI NETO, 1994). Between species of highgrade timber, there are few studies on the subject. In Brazil, the Australian cedar crop has gained popularity as it is well adapted to edafoclimatic conditions, and has a high timber potential (FERREIRA et al., 2012), adapting best in areas with an annual rainfall equal to or greater than $1,100 \mathrm{~mm}$, and in frost-free areas with good drainage. A cedar crop can be established at low or high altitudes (up to $1,700 \mathrm{~m}$ ), being more sensitive to higher altitudes (LORENZI et al., 2003; SOUZA; BARROSO; CARNEIRO, 2010). This species has a high nutritional requirement, as well as it less tolerant to soil acidity (BENATTI et al., 2012; BRAGA, 2011).

Australian cedar belongs to the family Meliaceae; it is a large tree that can attain a height of up to $40 \mathrm{~m}$ and diameter (at chest height) of up to
$1.0 \mathrm{~m}$, according to Bygrave and Bygrave (2005). Vilela and Stehling (2012) reported that this species has the potential to achieve an average annual increase of $30 \mathrm{~m}^{3} \mathrm{ha}^{-1} \mathrm{yr}^{-1}$, depending on good cultivation conditions, such as soil, climate, precipitation, and crop treatment. The wood of this species can be used for various purposes, timber being its primary use (SOUZA; BARROSO; CARNEIRO, 2010). Despite the high adaptability of this species in the country, research on its cultivation is still needed, since there is little information about the adequate silvicultural practices for its management.

This study was carried out in order to characterize and differentiate, at the seedling stage, four Australian cedar clones concerning the nutrient uptake capacity, by determining the root morphology characteristics and kinetic parameters of the $\mathrm{P}, \mathrm{K}$, $\mathrm{Ca}$, and $\mathrm{Mg}$ uptake.

\section{MATERIAL AND METHODS}

The experiment was initially conducted in the greenhouse, and then in a growth chamber, at the Soil Science Department of the Federal University of Lavras. Four different Australian cedar seedling clones were used, from the company, Bela Forest View (Bela Vista Florestal), located in the municipality of Campo Belo, MG. Genetic lines were designated as clones $\mathrm{HE}, \mathrm{XF}, \mathrm{XD}$, and $\mathrm{XE}$, originating from vegetative propagation, and with an average age of 60 days. The treatments included four clones, in a completely randomized design, with five repetitions, totaling twenty experimental plots.

The initial cultivation of seedlings was carried out for a period of 35 days in a greenhouse with $50 \%$ shade. At this stage, the seedlings of each clone were transferred to trays containing $42 \mathrm{~L}$ of Clark's solution (Clark, 1975), with the $\mathrm{pH}$ adjusted to $6.0 \pm$ 0.2 with $\mathrm{HCl}$ or $\mathrm{NaOH}$, and continuous aeration. To adjust the plants to the new environment, acclimation of the same clones was carried out, with a gradual increase (weekly) in the ionic strength of the solution, starting out with $25 \%$, and increasing to $100 \%$. During this period, the $\mathrm{pH}$ of the solution was adjusted daily to $6.0 \pm 0.2$.

After this acclimation phase, the seedlings were selected for uniformity of the roots and shoots and placed in individual pots, with an aeration system, containing $2 \mathrm{~L}$ of Clark's solution, and maintained in a growth chamber under controlled conditions of light intensity (approximately 100 $\mu \mathrm{mol} \mathrm{m} \mathrm{m}^{-2} \mathrm{~s}^{-1}$ ), photoperiod (14 hours of light) and temperature $\left(25 \pm 1^{\circ} \mathrm{C}\right)$. The seedlings remained in this condition for a period of five days, and the $\mathrm{pH}$ of the solution was adjusted daily to $6.0 \pm 0.2$. The nutrient solution was changed following this period for one with $10 \%$ the ionic strength of Clark's 
solution, and the seedlings remained in this solution for another five days.

To measure the uptake kinetics of phosphorus $(\mathrm{P})$, potassium $(\mathrm{K})$, calcium $(\mathrm{Ca})$, and magnesium $(\mathrm{Mg})$, the seedling solution was changed to one containing $\mathrm{N}\left(150 \mu \mathrm{mol} \mathrm{L}^{-1}\right), \mathrm{K}\left(70 \mu \mathrm{mol} \mathrm{L}^{-1}\right), \mathrm{P}(20$ $\left.\mu \mathrm{mol} \mathrm{L}{ }^{-1}\right), \mathrm{Ca}\left(40 \mu \mathrm{mol} \mathrm{L} \mathrm{L}^{-1}\right), \mathrm{Mg}\left(20 \mu \mathrm{mol} \mathrm{L}{ }^{-1}\right)$, and $\mathrm{S}$ $\left(25 \mu \mathrm{mol} \mathrm{\textrm {L } ^ { - 1 }}\right)$. The initial concentration of each nutrient in this solution was determined by preliminary tests to achieve a $\mathrm{C}_{\min }$ within 24 hours. Nutrient sources were as follows: $\mathrm{Ca}\left(\mathrm{H}_{2} \mathrm{PO}_{4}\right) \cdot \mathrm{H}_{2} \mathrm{O}$, $\mathrm{Ca}\left(\mathrm{NO}_{3}\right)_{2} \cdot 4 \mathrm{H}_{2} \mathrm{O}, \mathrm{KNO}_{3}, \mathrm{MgSO}_{4} \cdot 7 \mathrm{H}_{2} \mathrm{O},\left(\mathrm{NH}_{4}\right)_{2} \mathrm{SO}_{4}$, and $\mathrm{NH}_{4} \mathrm{NO}_{3}$ salts for analysis.

To apply the kinetic model proposed by Epstein and Hagen (1952), the seedlings remained in this pre-exhaust solution for two hours, to achieve a steady state of uptake. Afterwards, the solution was changed for another of equal composition, representing the depletion solution. In both solutions, the $\mathrm{pH}$ was adjusted to $6.0 \pm 0.2$.

Determination of the kinetic parameters $\mathrm{V}_{\max }$, $\mathrm{K}_{\mathrm{m}}$ and, $\mathrm{C}_{\mathrm{m}}$ was based on the principle proposed by Claassen and Barber (1974), which involves quantifying the reduction in nutrient concentration in the solution resulting from the uptake by the plants. For this, aliquots of $10 \mathrm{~mL}$ were removed from the depletion solution, the first being collected at "time zero," before adding the seedlings, and the others at intervals of one hour over a period of 12 hours. The last collection was made 24 hours after the commencement of the exhaustion period. Then the plants were separated into shoots and roots, and the fresh mass of the root was determined using a digital scale (precision $0.01 \mathrm{~g}$ ). The remaining volume in all pots was also measured using a graduated cylinder.

The levels of $\mathrm{Ca}$ and $\mathrm{Mg}$ present in the collected aliquots were determined by atomic absorption spectrophotometry, $\mathrm{K}$ by flame emission photometry, and the $\mathrm{P}$ by colorimetry. With nutrient concentrations determined for each sample as a function of time, volumes of the initial and final solutions in each pot, and the fresh root mass, $\mathrm{V}_{\max }$ and $\mathrm{K}_{\mathrm{m}}$ were calculated using the Kinetics 2.0 software (RUIZ; FERNANDES FILHO, 1992). For the $C_{\min }$ value, nutrient concentrations present in the depleted solution after 24 hours were calculated. The liquid inflow (IL) was estimated according to Equation 1, as proposed by Michaelis-Menten and modified by Nielsen and Barber (1978).

\section{$\mathrm{IL}=[\mathrm{Vmax}(\mathrm{C}-\mathrm{Cmin})][\mathrm{Km}+(\mathrm{C}-\mathrm{Cmin})]$}

After separating the shoots and roots, they were washed in distilled water and placed in plastic pots containing $70 \%$ alcohol, to determine the length, volume, surface area, average diameter, and extension of roots per diameter class. These characteristics were analyzed at EMBRAPA Maize and Sorghum (CNPMS) using WinRHIZO Pro 2007a (Regent Instr. Inc.) coupled to a professional scanner, Epson XL10000, equipped with an additional light unit (TPU).

The data was submitted to a variance analysis and a Scott \& Knott means test at 5\%, to compare the genetic sequences. The statistical program SISVAR was used (FERREIRA, 2011) to perform the statistical analyses.

\section{RESULTS AND DISCUSSION}

\section{Root morphology}

The average values for the root morphological characteristics of Australian cedar are found in Table 1. These variables differ significantly between the genetic sequences analyzed, except in the average diameter (Table 1).

Table 1. Average values of the variables of root morphology for four Australian cedar clones.

\begin{tabular}{ccccc}
\hline \multirow{2}{*}{ Clone } & Length* & Volume* & Surface area* & Average diameter \\
\cline { 2 - 5 } & $\mathrm{cm}$ & $\mathrm{cm}^{3}$ & $\mathrm{~cm}^{2}$ & $\mathrm{~mm}$ \\
\hline $\mathrm{HE}$ & $5,332.29 \mathrm{~b}^{(1)}$ & $12.61 \mathrm{~b}$ & $889.32 \mathrm{~b}$ & $0.60 \mathrm{a}$ \\
$\mathrm{XF}$ & $4,579.29 \mathrm{c}$ & $15.98 \mathrm{a}$ & $885.85 \mathrm{~b}$ & $0.64 \mathrm{a}$ \\
$\mathrm{XD}$ & $5,798.77 \mathrm{a}$ & $16.19 \mathrm{a}$ & $1,084.59 \mathrm{a}$ & $0.59 \mathrm{a}$ \\
$\mathrm{XE}$ & $4,117.92 \mathrm{~d}$ & $11.39 \mathrm{~b}$ & $844.93 \mathrm{~b}$ & $0.60 \mathrm{a}$ \\
\hline Average & $4,957.07$ & 14.04 & 926.17 & 0.61 \\
\hline $\mathrm{CV}(\%)^{(2)}$ & 5.39 & 12.40 & 8.91 & 6.09 \\
\hline
\end{tabular}

* Significant at $5 \%$ probability, by test $\mathrm{F}{ }^{(1)}$ Values followed by the same letter in each column do not differ amongst themselves (Scott-Knott, $5 \%$ ). ${ }^{(2)} \mathrm{CV}$ - coefficient of variation of averages between the clones.

Clone XD stood out, due to its higher averages compared to the other four clones, for length and surface area of the roots. Together with clone XF, clone XD also showed an increased root volume. Finally, clones $\mathrm{HE}$ and $\mathrm{XE}$ presented the lowest growth of the root system (Table 1).

Previous studies indicate that surface area and length would be the most important root morphological characteristics indicating the absorption efficiency of water and nutrients by different species. Zonta et al. (2006) reported that a root system with a greater length indicates an increased capacity for soil exploration, and Barber (1995) points out that evaluation of the root area 
becomes a parameter of interest in the uptake of scarcely mobile nutrients in the soil, such as potassium and phosphorus. For these elements, diffusion constitutes the principal movement mechanism in the soil, the diffusion rate being directly proportional to the surface area of the roots.

The morphological and physiological characteristics of roots and soil factors affect nutrient uptake by the roots. According to Alves et al. (2002), the morphological characteristics can be considered crucial when root access to nutrients is a limiting factor, indicating the importance of genetic differences in the morphology of the root system, as these interfere directly in the adaptive capacity of a species to variations in the availability of nutrients. It is also noteworthy that the concentration of existing transporters in the root cell membranes, as well as their conversion speed, may result in differences in the uptake efficiency of nutrients by plants (VALE et al., 1984).

Regarding the percentage of roots as a function of the different diameter classes, it was observed that about $99 \%$ of the root system for all clones is formed by thin absorbent roots (RFA) with diameters less than $3.0 \mathrm{~mm}$ (Figure 1). The RFA are the principal roots responsible for the uptake of water and nutrients by plants (FITTER, 1991).

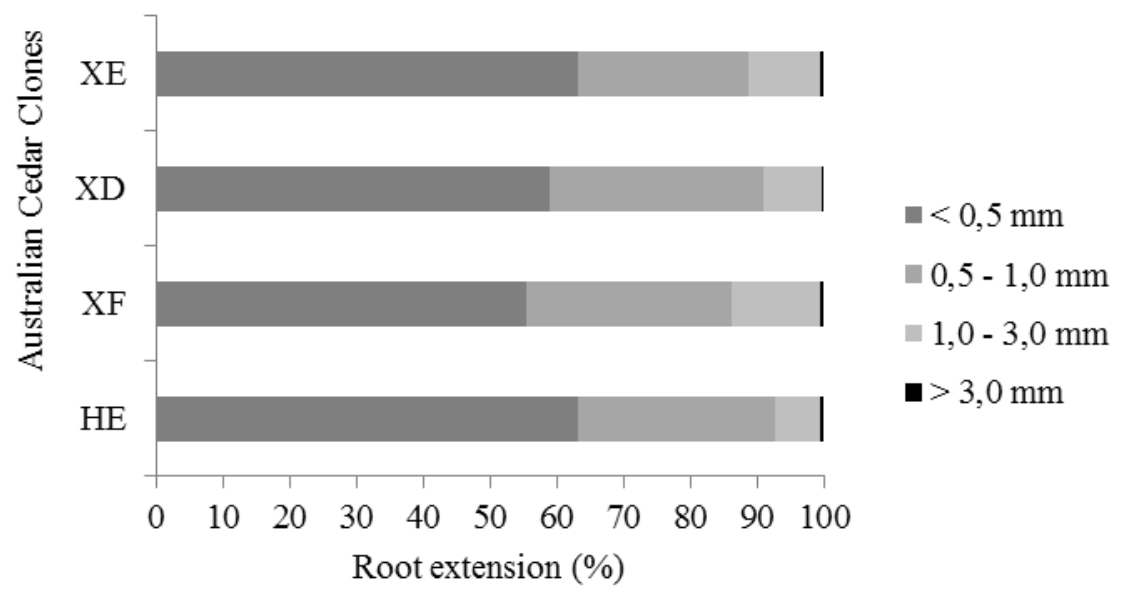

Figure 1. Root extension in different diameter classes for the four Australian cedar clones.

A tree species with a higher RFA percentage is a desirable feature, since it can increase water and nutrient uptake capacity, particularly in soils with low fertility, and it contributes to the selection of more efficient genotypes for nutrient utilization. However, the assessment mechanisms involved in nutrient uptake efficiency, such as the kinetic parameters associated with root morphology, can infer a higher or lower nutrient utilization potential for the genetic lines tested.

\section{Kinetic parameters of $\mathrm{P}, \mathrm{K}, \mathrm{Ca}$, and $\mathrm{Mg}$ uptake}

The Australian cedar clones presented typical exhaust curves for $\mathrm{P}, \mathrm{K}, \mathrm{Ca}$, and $\mathrm{Mg}$, the $\mathrm{V}_{\max }$ being determined from a linear equation, and $\mathrm{K}_{\mathrm{m}}$ through exponential equations for $\mathrm{P}$ and potential for $\mathrm{K}, \mathrm{Ca}$, and $\mathrm{Mg}$, as these were a better fit to the data. Table 2 shows the average test results for the kinetic uptake parameters of $\mathrm{P}$ and $\mathrm{K}$ for the Australian cedar clones, respectively.

Table 2. $\mathrm{V}_{\max }, \mathrm{C}_{\min }$, and $\mathrm{K}_{\mathrm{m}}$ for $\mathrm{P}$ and $\mathrm{K}$ of four Australian cedar clones.

\begin{tabular}{|c|c|c|c|c|c|c|}
\hline \multirow[b]{2}{*}{ Clone } & \multicolumn{3}{|c|}{ Phosphorous } & \multicolumn{3}{|c|}{ Potassium } \\
\hline & $\mathrm{V}_{\max } *$ & $\mathrm{C}_{\min } *$ & $\mathrm{~K}_{\mathrm{m}}{ }^{*}$ & $\mathrm{~V}_{\max } *$ & $\mathrm{C}_{\min }$ & $\mathrm{K}_{\mathrm{m}} *$ \\
\hline & $\mu \mathrm{mol} \mathrm{g}^{-1} \mathrm{~h}^{-1}$ & & & $\mu \mathrm{mol} \mathrm{g}{ }^{-1} \mathrm{~h}^{-1}$ & & \\
\hline $\mathrm{HE}$ & $0.05 \mathrm{~b}^{(1)}$ & $3.63 \mathrm{~b}$ & $4.93 b$ & $0.22 \mathrm{~b}$ & $25.20 \mathrm{a}$ & $27.70 \mathrm{~b}$ \\
\hline $\mathrm{XF}$ & $0.09 \mathrm{a}$ & $2.40 \mathrm{~b}$ & $7.26 a$ & $\mathrm{nd}^{(2)}$ & $\mathrm{nd}^{(2)}$ & $\mathrm{nd}^{(2)}$ \\
\hline XD & $0.06 \mathrm{~b}$ & $3.17 \mathrm{~b}$ & $4.97 \mathrm{~b}$ & $0.09 \mathrm{c}$ & $21.30 \mathrm{a}$ & $22.90 \mathrm{~b}$ \\
\hline $\mathrm{XE}$ & $0.06 \mathrm{~b}$ & $5.53 \mathrm{a}$ & $7.69 \mathrm{a}$ & $0.30 \mathrm{a}$ & $20.07 \mathrm{a}$ & $35.20 \mathrm{a}$ \\
\hline Average & 0.07 & 3.70 & 6.21 & 0.20 & 13.59 & 28.58 \\
\hline $\mathrm{CV}(\%)^{(3)}$ & 16.02 & 16.74 & 15.94 & 10.62 & 21.09 & 18.89 \\
\hline
\end{tabular}

*Significant at $5 \%$ probability through test $\mathrm{F}$. $\mathrm{V}_{\max }$ : maximum rate of uptake; $\mathrm{C}_{\min }$ : the minimum concentration for uptake within 24 hours; $\mathrm{K}_{\mathrm{m}}$ : concentration for half the maximum speed. ${ }^{(1)}$ Values followed by the same letter in each column do not differ amongst themselves (Scott-Knott, $5 \%$ ). $\mathrm{nd}^{(2)}=$ not determined (lack of fit of the data to the kinetic model).

${ }^{(3)} \mathrm{CV}$ - coefficient of variation of the averages between the clones. 
Due to the complexity involved plant nutrient uptake mechanisms, the uptake kinetics in this study were measured using a low concentration of $\mathrm{P}, \mathrm{K}$, $\mathrm{Ca}$, and $\mathrm{Mg}$, to determine only the first adsorption isotherm of the nutrients, which corresponds to a high-affinity, and to consider the possible interactions (antagonism/synergism) between the ions in the solution that may occur during uptake by the plant.

For $\mathrm{P}$, clone $\mathrm{XF}$ showed a higher $\mathrm{V}_{\max }$, compared to other clones. Smaller $\mathrm{C}_{\min }$ values for $\mathrm{P}$ were found for clones $\mathrm{XF}, \mathrm{XD}$, and $\mathrm{HE}$, which did not differ amongst themselves. Clones HE and XD showed lower $K_{m}$ values for P uptake (Table 2).

The kinetic parameters vary, especially with genotype and species (ALI et al., 2010; BRIX et al., 2010; LIMA et al., 2005; McFARLANE; YANAI, 2006; PINTO, 2009; SCHONINGER; GATIBONI; ERNANI, 2013; SILVEIRA; CARDOSO, 2004), as they determine the characteristics of the plant itself, and provide it with a higher or lower nutrient uptake capacity at a given concentration in the external medium. A genotype or species is considered efficient in the uptake of a particular nutrient when it presents kinetic parameters that qualify it as such. In principle, it would be expected that the plant achieves a high initial rate of nutrient uptake as a consequence of an existing high-affinity between the transporter and the element, resulting from a low $\mathrm{K}_{\mathrm{m}}$ value, and when extracting the maximum possible amount of the nutrient, low concentrations are found in the soil solution $\left(\mathrm{C}_{\min }\right)$ (NIELSEN; BARBER, 1978).

The value of $V_{\max }$ is indicative of the maximum uptake of an ion when there is saturation at all transport sites in the roots, or when the conversion of these transporters has reached a maximum. Thus, it is suggested that clone XF would have a higher concentration of $\mathrm{P}$ uptake sites than would the other genetic lines, or the conversion of these transporters in the plasma membrane was elevated, indicating that, probably, this clone has the greatest potential to respond to an increased investment in phosphate fertilizers.

$\mathrm{C}_{\min }$ is a kinetic parameter that indicates the potential of the plant to extract nutrients from the soil solution (MARSCHNER, 2012), and lower values indicate that the plant is able to utilize lower nutrient levels in the soil solution. From a practical point of view, this implies a greater potential for cultivation under conditions of low soil nutrient availability. In this context, clones $\mathrm{XF}, \mathrm{XD}$, and $\mathrm{HE}$ were able to extract the maximum $\mathrm{P}$ from the nutrient solution within 24 hours, owing to their lower $\mathrm{C}_{\min }$ values (Table 2).

$\mathrm{K}_{\mathrm{m}}$ represents the affinity that the transporter has with the ion (EPSTEIN; HAGEN, 1952), and the lower the value, the greater the affinity. The results suggest a greater affinity of $\mathrm{P}$ transporters present in the roots of clones HE and XD (Table 2).

The genotypes analyzed showed different $\mathrm{V}_{\max }$ values for $\mathrm{K}$ (Table 2), clone $\mathrm{XE}$ being a genetic line with greater potential for soil nutrient uptake, with low or high availability owing to its greater $\mathrm{V}_{\max }$; clone $\mathrm{XD}$, with the lowest $\mathrm{V}_{\max }$, suggesting a lower capacity for $\mathrm{K}$ utilization under distinct conditions of nutrient availability in the soil; and clone $\mathrm{HE}$ showed an intermediate $\mathrm{V}_{\max }$ value, which can be considered interesting from a nutritional point of view. According to Furtini Neto (1994), plants with intermediate $V_{\max }$ values appear to have a more accurate nutrient uptake mechanism, since regulation of its utilization may prevent excess uptake, which could lead to possible toxicity.

For $\mathrm{K}$, the $\mathrm{C}_{\min }$ values obtained for the tested clones did not distinguish them, as there was no significant difference between them $(\mathrm{P}<0.05)$ (Table 2). However, clones XD and HE showed lower $\mathrm{K}_{\mathrm{m}}$ values compared with the value presented for clone XE.

In an uptake kinetics study of macronutrients performed by Lima et al. (2005) involving four eucalyptus clones, no significant differences were observed in $\mathrm{K}_{\mathrm{m}}$ and $\mathrm{C}_{\mathrm{min}}$ values for $\mathrm{K}$. In this case, only the $\mathrm{V}_{\max }$ values distinguished uptake ability between the clones.

Importantly, in soils with restrictions on $\mathrm{P}$ and $\mathrm{K}$ availability, even with added supply via fertilization, $\mathrm{V}_{\max }$ is no longer the kinetic parameter that most influences the uptake of these nutrients; instead, it is controlled by $\mathrm{K}_{\mathrm{m}}$ (ERNANI et al., 1994). This occurs because the $\mathrm{P}$ and $\mathrm{K}$ move to the roots by diffusion, which, according to Barber (1995), occurs by the formation of a depletion zone in the soil near the roots where $\mathrm{V}_{\max }$ is usually not achieved. Under these conditions, $\mathrm{K}_{\mathrm{m}}$ would be the most important kinetic parameter in nutrient uptake, especially in soils with medium to low availability of these nutrients. In this case, lower $\mathrm{K}_{\mathrm{m}}$ values are more convenient than large $\mathrm{V}_{\max }$ values (NOVAIS; MELO, 2007). Thus, clones HE and XD would be more effective in the uptake of these nutrients in the solution.

Root nutrient inflow rates were also estimated, which represents the nutrient uptake rate per unit of fresh root material per unit of time. Obtaining root inflow rates can assist in a better distinction of clones as to the ability to absorb the nutrients evaluated. The combined effect of $V_{\max }$, $\mathrm{C}_{\text {min }}$, and $\mathrm{K}_{\mathrm{m}}$, represented by the estimated inflow of $\mathrm{P}$, showed that clone XF had higher inflow values than those obtained by the clones $\mathrm{XD}, \mathrm{HE}$, and $\mathrm{XE}$ (Figure 2). 


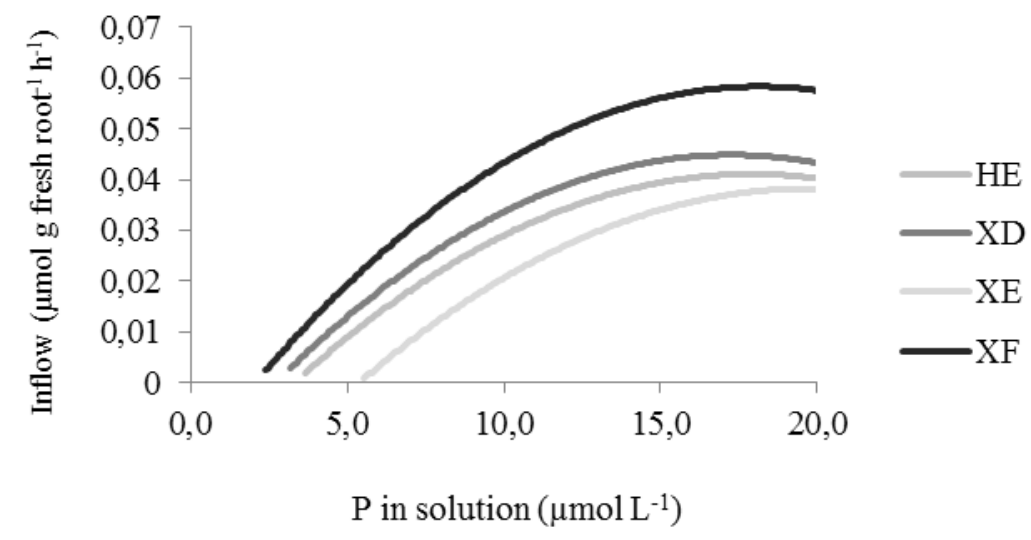

Figure 2. Estimated inflows as a function of $\mathrm{P}$ concentration for four Australian cedar clones

The $\mathrm{XF}$ clone exhibited a greater $\mathrm{P}$ inflow because of its high $\mathrm{V}_{\max }$ value and lower $\mathrm{C}_{\min }$ value (Table 2). Despite this line having shown a higher $\mathrm{K}_{\mathrm{m}}$ value, a greater root nutrient inflow was observed, suggesting that other mechanisms might be involved in the uptake efficiency of $\mathrm{P}$ by this clone. One possible explanation could probably be related to greater concentration and/or, conversion speed of the transporters present in its root system, resulting in a greater uptake of this nutrient (VALE et al., 1984). Mainly due to lower $\mathrm{V}_{\max }$ values, clones XD, HE, and $\mathrm{XE}$ all exhibited a lower inflow of $\mathrm{P}$ (Figure 2), suggesting that these genotypes may have a decreased ability to absorb $\mathrm{P}$ during both high and low nutrient availability, when compared to clone XF.

The different inflows of $\mathrm{K}$ could be observed for the analyzed clones, which allowed them to be separated according to their ability to utilize this nutrient solution (Figure 3): the largest inflow was obtained by clone XE; intermediate inflow was presented by clone HE; and the lowest inflow, by clone XD. These differences, in principle, were due to changes in $\mathrm{V}_{\max }$ exhibited by the tested clones (Table 2). Additionally, the curve of clone XD was above the curve of clone $\mathrm{HE}$ for lower concentrations of $\mathrm{K}$ in the solution. However, this clone achieved higher inflows when the concentration of the nutrient was greater than 28 $\mu$ mol $\mathrm{L}^{-1}$. This finding can be explained by the higher $\mathrm{V}_{\max }$ value obtained by clone $\mathrm{HE}$, compared to clone $\mathrm{XD}$, because the $\mathrm{K}_{\mathrm{m}}$ values for $\mathrm{K}$ exhibited no significant difference between these clones. The inflow of clone XF was not calculated due the data not fitting the kinetic model.

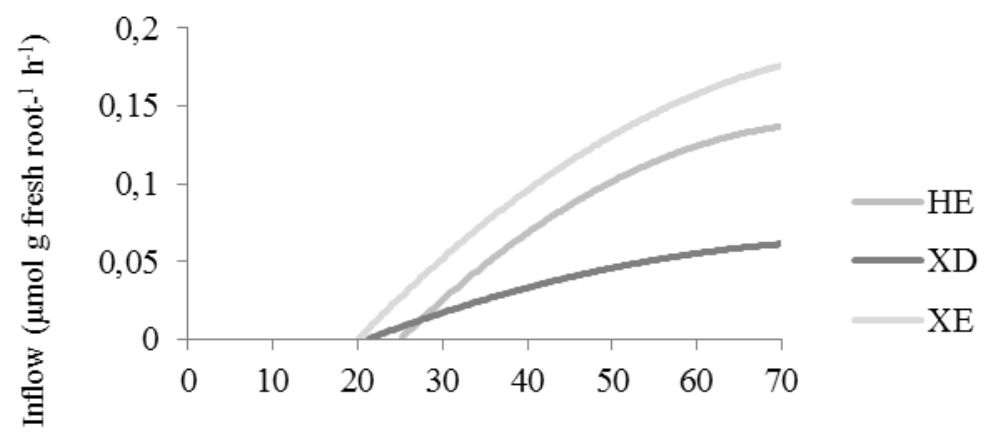

$\mathrm{K}$ in solution $\left(\mu \mathrm{mol} \mathrm{L} \mathrm{L}^{-1}\right)$

Figure 3. Estimated inflows as a function of $\mathrm{K}$ concentration for three Australian cedar clones.

The average values of the kinetic parameters obtained with $\mathrm{Ca}$ and $\mathrm{Mg}$ uptake by Australian cedar clones are shown in Table 3. The highest $\mathrm{V}_{\max }$ values were presented for $\mathrm{Ca}$ by clones $\mathrm{HE}$ and $\mathrm{XF}$, which did not differ amongst themselves $(\mathrm{P}<0.05)$, and clone XD, followed by clone XE (Table 3), achieved lower values for this parameter. In relation to the $\mathrm{C}_{\text {min }}$ of $\mathrm{Ca}$ in the solution, clones $\mathrm{HE}$ and $\mathrm{XE}$, followed by clone $\mathrm{XD}$, exhibited the lowest concentrations in the solution. The $\mathrm{K}_{\mathrm{m}}$ values for calcium inflow across the clones varied per the following order: $\mathrm{XE}<\mathrm{XD}<\mathrm{HE}=\mathrm{XF}$. In the case of $\mathrm{Mg}$, the largest $\mathrm{V}_{\max }$ value for the uptake of this nutrient was exhibited by clone HE. Clones $\mathrm{HE}$ and $\mathrm{XD}$ exhibited the lowest $\mathrm{Mg} \mathrm{C}_{\min }$ values, and clone $\mathrm{XD}$, followed by clones $\mathrm{XE}$ and $\mathrm{HE}$, exhibited the lowest $\mathrm{K}_{\mathrm{m}}$ values (Table 3). 
Table 3. $\mathrm{V}_{\max }, \mathrm{C}_{\min }$, and $\mathrm{K}_{\mathrm{m}}$ for $\mathrm{Ca}$ and $\mathrm{Mg}$ presented by four Australian cedar clones.

\begin{tabular}{|c|c|c|c|c|c|c|}
\hline \multirow[b]{2}{*}{ Clone } & \multicolumn{3}{|c|}{ Calcium } & \multicolumn{3}{|c|}{ Magnesium } \\
\hline & $\mathrm{V}_{\max }{ }^{*}$ & $\mathrm{C}_{\min }{ }^{*}$ & $\mathrm{~K}_{\mathrm{m}}{ }^{*}$ & $\mathrm{~V}_{\max } *$ & $\mathrm{C}_{\min }{ }^{*}$ & $\mathrm{~K}_{\mathrm{m}}{ }^{*}$ \\
\hline & $\mu \mathrm{mol} \mathrm{g}{ }^{-1} \mathrm{~h}^{-1}$ & & & $\mu \mathrm{mol} \mathrm{g}{ }^{-1} \mathrm{~h}^{-1}$ & & \\
\hline $\mathrm{HE}$ & $0.53 \mathrm{a}^{(1)}$ & $14.13 \mathrm{c}$ & $30.46 a$ & $0.11 \mathrm{a}$ & $6.67 b$ & $14.40 \mathrm{~b}$ \\
\hline XF & $0.46 \mathrm{a}$ & $19.10 \mathrm{a}$ & $32.43 \mathrm{a}$ & $0.08 b$ & $10.33 \mathrm{a}$ & $19.38 \mathrm{a}$ \\
\hline XD & $0.26 b$ & $16.90 \mathrm{~b}$ & $27.55 \mathrm{~b}$ & $0.06 \mathrm{~b}$ & $7.90 \mathrm{~b}$ & $9.71 \mathrm{c}$ \\
\hline $\mathrm{XE}$ & $0.10 \mathrm{c}$ & $15.03 \mathrm{c}$ & $21.70 \mathrm{c}$ & $0.06 \mathrm{~b}$ & $9.27 \mathrm{a}$ & $12.69 \mathrm{~b}$ \\
\hline Average & 0.34 & 16.29 & 28.03 & 0.08 & 8.54 & 14.12 \\
\hline $\mathrm{CV}(\%)^{(2)}$ & 18.03 & 7.76 & 6.46 & 31.65 & 9.73 & 9.19 \\
\hline
\end{tabular}

*Significant at $5 \%$ probability through test $\mathrm{F} .{ }^{(1)}$ Values followed by the same letter in each column do not differ amongst themselves (Scott-Knott, $5 \%) .{ }^{(2)} \mathrm{CV}$ - coefficient of variation of the averages between the clones.

Since the acidity of the soil is corrected through the practice of liming, typically there is no limitation in the supply of $\mathrm{Ca}$ and $\mathrm{Mg}$ from the soil to the roots, suggesting that the $\mathrm{V}_{\max }$ is the parameter that most influences the quantity of nutrients taken up by plants under this condition. Thus, clones HE and XF (Table 3) would be able to absorb greater amounts of $\mathrm{Ca}$ in relation to others with high levels of this nutrient in the soil. For the uptake of $\mathrm{Mg}$, clone HE suggests a greater capacity for the utilization of this nutrient under this condition of availability (Table 3). However, under conditions of low availability associated with a greater affinity of the transporters present in the root system, it indicates that clones $\mathrm{XE}$ and $\mathrm{XD}$ would be more apt to absorb $\mathrm{Ca}$ and $\mathrm{Mg}$, respectively. Additionally, clone HE may also have a greater capacity to utilize these nutrients at low concentrations in the solution due to its higher $\mathrm{V}_{\max }$ values, and lower $\mathrm{C}_{\min }$ values (Table 3).

The estimated root inflow rates of $\mathrm{Ca}$ for four Australian cedar clones allowed for their separation as to the ability to take up nutrients, clone $\mathrm{HE}$ showed the highest ability, clones XF and XD showed intermediate ability, and clone XE showed a lower ability (Figure 4).

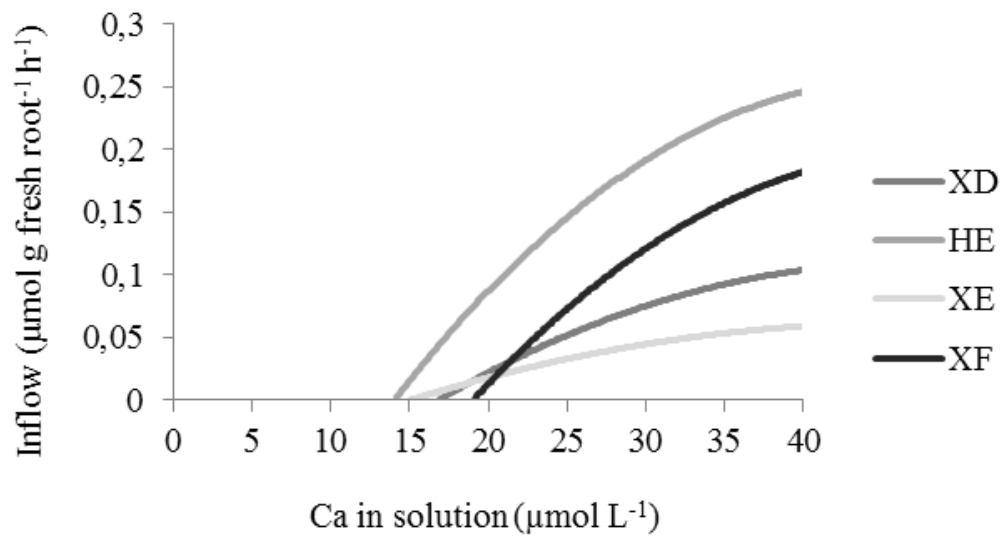

Figure 4. Estimated inflows as a function of Ca concentration for four Australian cedar clones.

The observed effect of the kinetic parameters on the root $\mathrm{Ca}$ inflow suggests that this physiological mechanism could be involved in the nutritional uptake efficiency of the Australian cedar, providing a larger or smaller nutrient uptake capacity (Figure 4). In this context, for clone $\mathrm{HE}$, the high $\mathrm{V}_{\max }$ value and the low $\mathrm{C}_{\min }$ value for $\mathrm{Ca}$ (Table 3 ) can provide a high uptake efficiency of this nutrient under conditions of increased and decreased availability of this element in the solution. In contrast, when clone $\mathrm{XE}$ was compared to the others, it had lower $\mathrm{Ca}$ inflows (Figure 4), mainly due to the lower $\mathrm{V}_{\max }$ values presented by this genetic material (Table 3).

The estimated inflow of $\mathrm{Mg}$ for the Australian cedar clones enabled them to be separated according to the highest and the lowest abilities to absorb this nutrient in the solution. Clone HE achieved higher estimated rates of $\mathrm{Mg}$ inflow (Figure 5) due to the high $\mathrm{V}_{\max }$ value and lower values of $\mathrm{C}_{\min }$ and $\mathrm{K}_{\mathrm{m}}$ (Table 3), which may provide a high uptake efficiency for this nutrient, and high plasticity to adapt to distinct soil fertility conditions in relation to the greater or lesser availability of this element in the solution. However, clones XD, XE, and XF represent a group with the lowest estimated inflows of $\mathrm{Mg}$, due mainly to lower values of $\mathrm{V}_{\max }$ obtained by these genetic lines. 


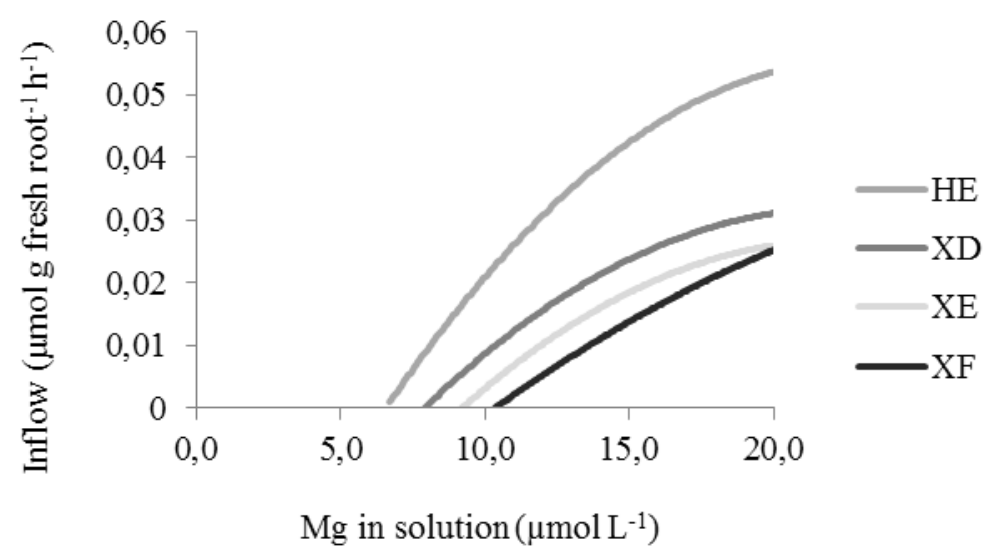

Figure 5. Estimated inflows as a function of $\mathrm{Mg}$ concentration for four Australian cedar clones.

The kinetic parameters of $\mathrm{P}, \mathrm{K}, \mathrm{Ca}$, and $\mathrm{Mg}$ uptake allowed the Australian cedar clones to be distinguished according to their capacity for nutrient utilization under different levels of nutrient availability. However, for each adjustment in soil fertility parameters, new experiments are required, especially in the field, to validate the results obtained, so that it is possible to optimize the genotype-environment interaction of the tested clones. Such information can assist in the verification of the existing correlation between the nutritional efficiency of juvenile and adult trees.

\section{CONCLUSIONS}

The root morphological characteristics vary among the Australian cedar clones. The Australian cedar clones exhibit distinct behaviors with regard to the uptake efficiencies of $\mathrm{P}, \mathrm{K}, \mathrm{Ca}$, and $\mathrm{Mg}$. Under conditions of variations in availability, clones XF and $\mathrm{XE}$ present higher plasticity in the uptake of $\mathrm{P}$ and $\mathrm{K}$, respectively, and clone $\mathrm{HE}$ shows higher uptake of $\mathrm{Ca}$ and $\mathrm{Mg}$. Despite reduced root growth, clones $\mathrm{HE}$ and XE achieved a higher capacity for the uptake of $\mathrm{Ca}, \mathrm{Mg}$, and $\mathrm{K}$, respectively. However, clone XF had a greater root volume and increased ability to absorb $\mathrm{P}$. To validate the results obtained, it is necessary to conduct studies on adult trees under field conditions, to evaluate the nutritional behavior of these clones at forestry sites.

\section{ACKNOWLEDGEMENTS}

The authors acknowledge CAPES (Coordination for the Improvement of Higher Education Personnel), CNPq (National Council for Scientific and Technological Development), Fapemig (the State of Minas Gerais Research Foundation) and Bela Vista Florestal for the support in the realization of this work.

\section{REFERENCES}

ABICHEQUER, A. D.; BOHNEN, H. Morfologia e distribuição de raízes de arroz irrigado por inundação e sua relação com a absorção de nutrientes e o rendimento de grãos. Pesquisa Agropecuária Gaúcha, Porto Alegre, v. 14, n. 1, p. 13-20, 2008.

ALI, L. et al. Differential potassium influx in fluences growth of two cotton varieties in hydroponics. Pakistan Journal of Botany, Karachi, v. 42, n. 2, p. 943-953, 2010.

ALVES, F. A. L. et al. Cinética de absorção de $\mathrm{K}^{+}$na ausência e presença de $\mathrm{Na}^{+}$em raízes de cajueiro. Revista Ciência Agronômica, Fortaleza, v. 43, n. 3, p. 439-445, 2012.

ALVES, V. M. C. et al. Cinética de absorção de fósforo e crescimento do sistema radicular de genótipos de milho contrastantes para eficiência a fósforo. Revista Brasileira de Milho e Sorgo, v. 1, n. 1, p. $85-92,2002$.

ANGHINONI, I. et al. Morfologia de raízes e cinética da absorção de nutrientes em diversas espécies e genótipos de plantas. Revista Brasileira de Ciência do Solo, Viçosa, v. 13, n. 3, p. 355-361, 1989.

BARBER, S. A. Soil nutrient bioavailability: a mechanistic approach. 2. ed. New York, NY: John Wiley \& Sons, 1995. 414 p.

BENATTI, B. P. et al. Development of clonal matrices of australian red cedar in different substrates under fertilizer doses. Ciência e Agrotecnologia, Lavras, v. 36, n. 3, p. 285-293, 2012.

BRAGA, M. M. Crescimento e qualidade de mudas de cedro-australiano (Toona ciliata $M$. Roem var. australis) em função da aplicação de 
calcário e enxofre. 2011. 81 p. Dissertação (Mestrado em Ciência do Solo: Área de Concentração em Fertilidade do Solo e Nutrição Mineral de Plantas) - Universidade Federal de Lavras, Lavras, 2011.

BRIX, H. et al. Can differences in phosphorus uptake kinetics explain the distribution of cattail and sawgrass in the Florida Everglades? BMC Plant Biology, London, v. 10, n. 23, p. 1-14, 2010.

BYGRAVE, F. L.; BYGRAVE, P. L. Growing Australian red cedar. Canberra, NSW: RIRDC/ Land; Water Australia/FWPRDC/MDBC Joint Venture Agroforestry, 2005. 84 p.

CLAASSEN, N.; BARBER, S. A.A method for characterizing the relation between nutrient concentration and flux into roots of intact plants. Plant Physiology, Illinois, v. 54, n. 4, p. 564-568, 1974.

CLARK, R. B. Characterization of phosphates of intact maize roots. Journal of Agricultural and Food Chemistry, Davis, v. 23, n. 3, p. 458-460, 1975.

ERNANI, P. R. et al. Prediction of phosphorus uptake by a mechanistic model in a low phosphorus highly weathered soil as affected by micorrhizae inoculation. Journal of Plant Nutrition, Philadelphia, v. 17, n. 6, p. 1067-1078, 1994.

ESPTEIN, E.; HAGEN, E. A kinetic study of the absorption of alkali cations by barley roots. Plant Physiology, Illinois, v. 27, n. 3, p. 457-474, 1952.

FERREIRA, D. de A. et al. Influência da posição das miniestacas na qualidade de mudas de cedroaustraliano e no seu desempenho inicial no pósplantio. Ciência Florestal, Santa Maria, v. 22, n. 4, p. 715-723, 2012.

FERREIRA, D. F. SISVAR: A Computer Statistical Analysis System. Ciência e Agrotecnologia, Lavras, v. 35, n. 6, p.1039-1042, 2011.

FITTER, A. H. Characteristics and function of root systems. In: Waisel,Y.; Eshel, A.; Kafkaki, U. (Ed.). Plant roots: the hidden half. New York: Marcel Dekker, Inc., 1991. v.1, cap. 2, p. 15-32.

FURTINI NETO, A. E. Eficiência nutricional, cinética de absorção e frações fosfatadas em Eucalyptus ssp. 1994. 105f. Tese (Doutorado em Ciência do Solo: Área de Concentração em Solos e Nutrição de Plantas) - Universidade Federal de Viçosa, Viçosa, 1994.
HORN, D. et al. Parâmetros cinéticos e morfológicos da absorção de nutrientes em cultivares de milho com variabilidade genética contrastante. Revista Brasileira de Ciência do Solo, Viçosa, v. 30, n. 1, p. 77-85, 2006.

LIMA, A. M. N. et al. Cinética de absorção e eficiência nutricional de $\mathrm{K}, \mathrm{Ca}$ e $\mathrm{Mg}$ em plantas jovens de quatro clones de eucalipto. Revista Brasileira de Ciência do Solo, Viçosa, v. 29, n. 6, p. 903-909, 2005.

LORENZI, H. et al. Árvores exóticas no Brasil: madeireiras, ornamentais e aromáticas. Nova Odessa SP: Instituto Plantarum, 2003. 368 p.

MARSCHNER, H. Mineral nutrition of higher plants. 3. ed. San Diego, CA: Academic Press, 2012. $651 \mathrm{p}$.

McFARLANE, K. J.; YANAI, R. D. Measuring nitrogen and phosphorus uptake by intact roots of mature Acer saccharum (Marsh), Pinusresinosa (Ait) and Piceaabies (L.) (Karst). Plant and Soil, Dordrecht, v. 279, n. 1-2, p. 163-172, 2006.

NIELSEN, N. E.; BARBER, S. A. Differences among genotypes of corn in the kinetics of $\mathrm{P}$ uptake. Agronomy Journal, Madison, v. 70, n. 5, p. $695-$ 698,1978

NOVAIS, R. F.; MELLO, J. W. V. Relação soloplanta. In: NOVAIS, R. F. et al. (Ed.). Fertilidade do solo. Viçosa: SBCS, 2007. v. 1, cap. 4, p. 133204.

PINTO, S. I. do C. Cinética de absorção conjunta de fósforo, potássio, cálcio e magnésio e eficiência nutricional de macronutrientes de clones de eucalipto. 2009. 109 f. Tese (Doutorado em Ciência do Solo: Área de Concentração em Fertilidade do Solo e Nutrição de Plantas) - Universidade Federal de Lavras, Lavras, 2009.

PINTO, S. I. do C. et al. Eficiência nutricional de clones de eucalipto na fase de mudas cultivados em solução nutritiva. Revista Brasileira de Ciência do Solo, Viçosa, v. 35, n. 2, p. 523-533, 2011.

RUIZ, H. A.; FERNANDES FILHO, E. I. Cinética: Software para estimar as constantes Vmax e Km da equação de Michaelis-Menten. In: REUNIÃO BRASILEIRA DE FERTILIDADE DO SOLO E NUTRIÇÃO DE PLANTAS, 10., 1992, Piracicaba. Anais... Piracicaba: SBCS, 1992. p. 124-125.

SAMAL, D. et al. Potassium uptake efficiency and dynamics in the rizosphere of maize (Zea mays L.), wheat (Triticum aestivum L.) and sugar beet (Beta 
vulgaris L.) evaluated with mechanistic model. Plant and Soil, Dordrecht, v. 332, n. 1-2, p. 105-121, 2010 .

SANES, F. S. M. et al. Morfologia de raízes e cinética de absorção de potássio em genótipos de arroz irrigado. Revista Brasileira de Ciência do Solo, Viçosa, v. 37, n. 3, p. 688-697, 2013.

SCHONINGER, E. L; GATIBONI, L. C.; ERNANI, P. R. Fertilização com fosfato natural e cinética de absorção de fósforo de soja e plantas de cobertura do cerrado. Semina: Ciências Agrárias, Londrina, v. 34, n. 1, p. 95-106, 2013.

SILVEIRA, A. P. D; CARDoso, E. J. B. N. Arbuscular mycorrhiza and kinetic parameteres of phosphorus absorption by bean plants. ScientiaAgricola, Piracicaba, v. 61, n. 2, p. 203-209, 2004.

SOUZA, J. C. A. V.; BARROSO, D. G.; CARNEIRO, J. G. A. Cedro-australiano (Toona ciliata). Niterói, RJ: Rio Rural, 2010. 12 p.

VALE, F. R. et al. Absorção de nitrato e amônio por raízes intactas de milho pré-tratadas com alumínio. Revista Brasileira de Ciência do Solo, Viçosa, v. 8, n. 2, p. 215-218, 1984.

VILELA, E. S.; STEHLING, E. de C. Recomendações de plantio para cedroaustraliano. Campo Belo: Bela Vista Florestal, 2012. Disponível em: <http:// www.belavistaflorestal.com.br/imagens/arquivos/ Cartilha_Cedro_ver1.2.pdf $>$. Acesso em: 29 maio 2014.

ZONTA, E. et al. O sistema radicular e suas interações com o ambiente edáfico. In: FERNANDES, M. S. (Ed.). Nutrição mineral de plantas. Viçosa: Sociedade Brasileira de Ciência do Solo, 2006. v. 1, cap. 2, p. 7-52. 